\title{
THE ROLE OF THE MEDIA IN A DEMOCRATIC COUNTRY
}

\author{
${ }^{1}$ Ibrahim T.I. Ukka
}

${ }^{1} \mathrm{Ph} . \mathrm{D}$. Candidate, School of Journalism and Information Communication,

Huazhong University of Science and Technology, 1037 Luoyu Rd. Wuhan 430074, China.

${ }^{2}$ Department of print and electronic journalism, An-Najah National University, Nablus, Palestine

*Corresponding Author: Ibrahim T.I. Ukka
${ }^{1}$ Corresponding Author Email: ibrahimokah@ hust.edu.cn

Article Received: $13-10-19 \quad$ Accepted: $30-11-19$
Published: 05-12-19

Licensing Details: Author retains the right of this article. The article is distributed under the terms of the Creative Commons Attribution-NonCommercial 4.0 License (http://www.creativecommons.org/licences/by-nc/4.0/) which permits non-commercial use, reproduction and distribution of the work without further permission provided the original work is attributed as specified on the Journal open access page.

\section{ABSTRACT}

The media is the fourth pillar of democracy after the executive, the legislature and the judiciary. Media as control over the three pillars and underpin their performance with checks and balances. to be able to perform its role should be upheld the freedom of the press in conveying public information in an honest and balanced manner. besides that also to uphold this fourth pillar, the media must also be free from capitalism and politics. Media that does not merely support the interests of the owners of capital and perpetuates political power without considering the interests of the larger society. the possibility of freedom of the press institution that is captured by the interests of capitalism and politics, encourages the spirit of citizen journalism. the term citizen journalism to explain the processing and presentation of news by citizens rather than professional journalists. journalism activities undertaken by citizens as a manifestation of aspirations and the delivery of popular opinion is the background that citizen journalism as part of the press is a means to achieve a democracy.

Keywords: Democracy, Media, Press, Journalism.

\section{INTRODUCTION}

More than an instrument used to relay government political propaganda, the media, in a democratic regime, must serve to convey a plural information, honest and taking into account the concerns of all citizens of any sensitivity, to pass to the sifts the action of the government, to organize debates which give public opinion the means of making themselves heard by the political authorities. This is all the more important since a government can only be truly 
legitimate and appreciable if it regularly informs citizens of its actions and gives it independent means to evaluate them. This is why the radio or television debates to which ministers and other public figures are invited, because they allow them to answer the questions put to them, seem to us of great interest. But all this can only be done if the media are truly independent of political, economic and religious power.

Today, the configuration of the media space must go beyond the traditional pattern representing on the one hand, a so-called state press focusing all its attention and all its genius on the activities of the government, or even the party in power and, on the other hand, a private press that wants to be independent (certainly of political power, but often controlled by economic lobbies), close to opponents of the regime in place, disadvantaged social groups and conveying information "fair, true and honest" . This is all the easier to realize that today, the state press has evolved a lot. This is why we believe that the press, as a whole, must strive towards a single goal: the production of programs and information that take into account the political, religious, social, ethnic, state linguistic diversity and respectful of the ethic and ethical rules governing the profession of journalist. But in the light of what is happening nowadays, researchers must recognize that the situation is not very good. But it has the merit of reinforcing vigilance to avoid democracy a decline compared to the achievements.

It must still be said that the excesses are not manifested only in the state media. At the level of private media, it noted the emergence of a certain press pouring into sensationalism, which, if it is not quickly channeled, can be a serious blow to the profession of journalist and call into question the foundations of the nation.

Indeed, today, after newsletters or the press of the colonial administration, the official press of independence, the press of opinion or political parties which has its roots in the colonial period, the private press of 1970, which developed in the 1990s, and the popular press (or news), we see emerge in the media space a new generation of newspapers or press groups in the pay of men or political parties. The problem is that they appear under the guise of general news journals when in reality they are real opinion journals.

Since national law does not prohibit a politician or his party from setting up a press group, parties or politicians are founded in this desire to equip themselves with press organs enabling them to convey their various messages. and to do, thus, their promotion. However, if we know the passion that characterizes the field of politics, the interests at stake and drifts we see daily, say that this activity must, in legal terms, be tightly framed is common sense.

\section{Function of Press in Democratic Nation}

The press is a social institution that is very important and indispensable for the community and a country that embraces the democratic system. Press in the democratic society life has an important role. With the press, the public can know quickly, precisely, and easy information which is needed or news that is growing. In addition, the press in this case the mass media can also be a two-way communication media, namely from society to country and also from state to society. Therefore, the press must play its part by supporting a more professional appearance in exposing the facts and more transparently in broadcasting information or news. Press and society have a close inner bond. Because the press and society are equally mutual need of one another. Press need support from the community, because without the press community will not 'live' and will not run smoothly. And so, does society, society without the presence of the press, then the community will be left behind all the 
information or news that is very important that is needed by the community. The community also will not be able to channel its aspirations and express themselves.

\section{1) Press as a channel for channeling community aspirations}

One of the roles of the press in a democratic society is the channel of the people's aspiration channel. Presses are very important and indispensable to the community as a 'tongue-tongue' of society for all its grievances to the state and government. Press can be very beneficial to society because of its role that channel all aspirations of the Society because without the presence of the press, it is very difficult for the public to convey the outpouring of his heart to the government agencies and his country(Blair \& Lacy, 1993).

\section{2) Press as a channel of education and learning to the community}

The role of the second press is as a channel of education and learning to the community. Press can provide education, insight, science, and educate the community. This is because people who intensively seek and get news from the press will be more knowledge, and the news in this press may be about economic, social, political, cultural, education, nature, tourism, sports, etc. Press in this case the mass media can also disseminate events, events, and all actions of citizens or certain groups to be known by the community (Tchakhotine, 1988).

\section{3) Press as a Channel of Government Programs and Public Policy to the Community}

The third role of the press is as a channel to report on programs being undertaken or implemented by the government, programs already undertaken by the government, and programs to be undertaken by the government, and disseminating various policies issued by the government for public interest. All of the new programs, decisions, policies and regulations of the government will accelerate to the public through intermediaries of the press rather than having to first meet one at a time with the community.

\section{4) Press as a Channel for Investigating on Public Issues}

The fourth role of the press in democratic societies and countries is the press as a channel or media to investigate and disclose public issues broadly to the public, such as official policies, development issues, programs and government efforts to the public. The press is very useful for the community, because the information previously closed and limited only in the government alone, can be open and known by the society. Press can conduct reports and indepth investigation of all public issues previously unknown by the society. For example to reduce investigation news about a corruption case in an environment of a department or a local government (Gitlin, 2009).

\section{5) Press as a Channel for Public Opinion and Public Debate}

The fifth role of the press in democratic societies and countries is as a channel for public opinion and public debate. Participants play a role in accommodating two-way means of communication from top to bottom or from bottom to top. Communication from top to bottom means communication from country to society and communication from the bottom up is the intention of the community (citizens) to the state or government. Through the public press can convey various aspirations, suggestions, criticism, and suggestions by the press to the country. This is then referred to as a channel for public opinion. become an effective means of accommodating the various aspirations of the people. In addition, the press also plays a role in facilitating the public or the general public to provide a forum for public 
debate for government leaders, party figures, public figures, and other public officials. Press can be a means to conduct a healthy debate freely, argue, discuss, and polemic about a thing through the press (mass media). So a problem can find common ground about the solution (McClung Lee, 1949).

\section{6) Press as a channel of information to the wider community}

The role of the sixth press is as a channel of information to the public. Press is very important presence for the community, because without the press, the public will not be able to know a variety of information about an event, events, technological developments in the latest, fast and easy. because the press plays a role in finding and disseminating news or an information intensively to the wider community (Bratic, 2008).

\section{7) Press as Channel of Supporting Components of Political Infrastructure or Supporting Political Progress}

The role of the seventh press is as a channel of supporting components of political infrastructure or advocating the progress of politics in a democratic (democratic) society. As a channel supporting the advancement of politics, the press plays a role in broadcasting or disseminating news about the world of politics, for example is spreading the word about vision and the mission of regional head candidates in each region, disseminating the news surrounding the campaign of candidates for the people's representatives who will sit in the seat of government, disseminating the news surrounding the existing political parties and its management structure. Disseminating news about the Vision and Mission respectively political parties, and disseminating news about vote counting in every 'party of the people' (elections) event (DERVILLE, 2017). Thus, then society will become more intelligent in determining its choice in every general election event.

\section{Journalism}

Along with the advance of information technology the printed daily report become daily newspaper. From the print media developed into electronic media, from the advancement of electronics created the information media in the form of radio. Not enough with the radio that just a sound emerged also a new breakthrough in the form of audio-visual media is TV (television). Media information is not satisfied only with television, was born in the form of the Internet, as a free and unlimited network. And now with the development of technology has spawned a lot of media (multimedia). Journalism can be limited briefly as an activity of preparing, writing, editing, and delivering news to audiences through certain media channels. Journalism covers activities from coverage to spread to the public. Previously, journalism in a narrow sense is also called a printed publication. The notion is not only limited through print media such as newspapers, magazines, and so on, but extends to electronic media such as radio or television (McCombs \& Shaw, 2016).

Based on the media used including print journalism (print journalism), electronic (electronic journalism). Lately also has been developing online journalism (online journalism). In the past, journalistic activities were carried out in a manual manner, ranging from news search to news reporting or news gathering in a very simple way. This is because the first tools supporting the activities of journalism is still very minimal. In addition, journalism in ancient times only understood as a print publication. But now not only from there alone, electronic media also contribute in terms of news and as perpetrators of mass media. It can be seen that today the world of technology is growing. The development of these technologies also affects 
the development of journalism. In ancient times only a professional journalist capable of journalistic activities. Where journalistic activities in question is to seek, collect, process, and report the news to the public. However, at this time, journalistic activities can not only be done by professional journalists (Katz \& Suchey, 1989).

With found of internet technology, journalistic activities can be done by anyone, without having a background as a professional journalist. Everyone can do activities to find, collect, process, and report the news to the public. The term used for the development of journalism is citizen journalism. In citizen journalism, all members of the community are able to conduct journalistic activities regardless of educational background and expertise. The presence of citizen journalism encourages everyone to dare to write and report information / news to many people without the need for professional labels or status journalists (Shanahan, Mcbeth, Hathaway, \& Arnell, 2008)

The meaning of journalism according to the is as follow:

1. Fraser Bond in his book, "An introduction to Journalism" published in 1961, argued that Journalism is all forms that make news and reviews of news to arrive at the group of observers.

2. Roland E. Wolseley, Journalism is the collection, writing, interpretation, processing and dissemination of general information, opinions of observers, public entertainment systematically and reliably to be published on magazines and broadcast stations.

3. Adinegoro in the book "Law Communications Journalism" the work of M. Djen Amar published in 1984, argued that Journalism is a kind of ingenuity that essentially give a message to the community with the haste to spread wide.

4. Astrid Susanto in his book: "Mass communication" published in 1986 defined Journalism as the activity of recording and / or reporting and dissemination of daily activities.

5. Onong Uchjana Effendy in his book: "Science Theory and Philosophy of Communication" published in 1993 mentioned that Journalism is a technique of managing news from getting the material to disseminate it to the public.

6. Djen Amar: in his book "Journalistic communications law" published in 1984 concluded that Journalism is an activity of collecting, processing and spreading the news to the widest audience as soon as possible.

7. Erik Hodgins, editor of Time magazine as quoted by Kustadi Suhandang in his book: "Introduction to Journalism, Organization, Product and Code of Ethics" published in 2004, argued that Journalism is sending information from here to it correctly, thoroughly and quickly in order to defend the truth and justice that can always be proven.

8. Kustadi Suhandang in the same book explain that Journalism is the art and / or skill of finding, collecting, processing, compiling, and presenting the news about everyday events beautifully, in order to meet all the needs of the conscience of the audience.

9. Drs. US. Haris Sumadiria, M.Si, in his book, "Indonesian journalism" defined Journalism as Writing news and features, Practical guide Professional journalist.

10. Simbiosa Rekatama (2005), formulated the definition of journalism as: Activities preparing, searching, collecting, processing, presenting, and spreading through the media periodically to the widest possible audience as soon as possible. 
As time goes by, facilitated by an increasingly loose regulatory environment, large media companies join or buy other media companies to make the media conglomerate larger and also global. Seen from a market-point of view, this is natural in order to increase sales, efficiency in production, and position itself against competitors. However, when viewed from the perspective of public space, this does not guarantee the serving of public interest. The number of media outlets that many do not necessarily guarantee the fulfillment of content into the public interest. Current trends in the structure of the media industry are Growth, Integration, Globalization, and Centralization of Ownership. The restructuring process in the media industry has allowed conglomerates to implement strategies aimed at maximizing profits, reducing costs, and minimizing risk. Changes in media structure and practice have a significant effect on media content. The pursuit of profits leads the media to homogenization and trivialization (making things unimportant). The content on the media will often clash and adjust to the profit-driven business interests. Hegemony, in Gramsci's (1971) not only shows dominance in economic and political control alone, but also shows the ability of a dominant social class to project their way of looking at the world. Thus, those who have positions under it accept it as a natural general assumption. Cultures that are spread evenly within a society at a certain time can be interpreted as the result or embodiment of hegemony, the embodiment of consensual acceptance by groups of subordinate ideas, values, and leadership of the dominant group. According to Gramsci, the dominant group seems not merely to maintain dominance by power, it may be because the public itself permits (Haase, Ge, Vedel, \& Calais, 2003).

In short, hegemony can be said to be a reproduction of obedience, a common view, in a soft way. Through mass media is hegemony done. Media gradually introduces, shapes, and imparts a particular view to audiences. The hegemonic concepts described above may still be somewhat confusing, so we will peel the application of media hegemony in a lighter example. The United States with its Hollywood has succeeded in becoming the mecca of international cinema. This condition is not wasted by them to drive the views of the world community towards their country. The United States is trying to build the view that their country is the strongest country, the superhero, the savior of the world. Take a look at science fiction films like Armageddon, Independence Day, and so on. Here the United States is always portrayed as a -game figure.

\section{Role of Journalist}

Journalist is someone who does journalism or people who regularly write news (in the form of reports) and his writings are sent / loaded in the mass media on a regular basis. This report can then be published in mass media, such as newspapers, television, radio, magazines, documentary films, and the internet. Journalists are looking for their source to be written in the report; and they are expected to write the most objective reports and have no view from a certain angle to serve the community. The term new journalist appeared after the influx of communication science that tend to be oriented to the United States. This term then affects the naming of journalism positions (Robinson, 2016).

At the time of the Alliance of Independent Journalists standing, there was an awareness of the term journalist. According to this alliance, journalist is a profession or naming someone whose job is related to the content of the mass media. Journalists include also columnist, freelance writer, photographer, and editorial graphic design. However, in reality the reference 
to its use, the term journalist refers more to the definition of journalists (Helmke \& Levitsky, 2004).

Meanwhile, journalists are relating to the writing activities of which seek data (research, coverage, verification) to complete the report. Journalists are required to be objective; this is different from the column writers who can put subjectivity. In the early nineteenth century, journalists meant someone who wrote for a journal, such as Charles Dickens at the beginning of his career. In the last century it means to have been a writer for newspapers as well as magazines. Many people think journalists are the same as reporters, someone who collects information and creates reports, or stories. However, this is not true because he does not cover other types of journalists, such as columnists, lead writers, photographers, and editorial designs. Regardless of the type of media, the term journalists brings connotation or professional expectancy in making reports, with truth and ethical considerations (Ukka \& Kombate, 2019).

The specific task of journalists is as follow:

1) Authenticator, i.e. consumers need a reporter who can check the authenticity of an information.

2) Sense maker that explains whether the information makes sense or not.

3) Investigators i.e. journalists should continue to oversee power and dismantle evil.

4) witness bearer that certain events should be researched and monitored again and can work together with citizen reporters.

5) Empowerers i.e. mutual empowerment between journalists and citizens to generate continuous dialogue on both.

6) Smart aggregator that intelligent reporters should share reliable news sources, enlightening reports, not just the work of the journalist himself.

7) Forum organizer i.e. news organization, both old and new, can function as a square where citizens can monitor the voice of all parties, not only their own group.

8) Role model, i.e. not only how the work and how journalists produce the work.

\section{CONCLUSION}

The role of the press in a democracy society, the press is one of the means for citizens to issue thoughts and opinions and has an important role in a democratic country. A free and responsible press plays an important role in a democratic society and is one of the elements of a democratic state and government. According to Miriam Budiardjo, one of the characteristics of a democratic country is to have a free and responsible press. Meanwhile, the essence of democracy is the opportunity for the aspirations and voices of the people (individuals) in influencing a decision. In Democracy also required the participation of the people, arising from political awareness to participate and share in the system of government. Various aspects of life in this country, the people actually have the right to participate in determining the policy steps of a State. the press is the fourth pillar of democracy after the executive, the legislature and the judiciary. press as. control over the three pillars and underpin their performance with checks and balances. to be able to perform its role should be upheld the freedom of the press in conveying public information in an honest and balanced manner. besides that, also to uphold this fourth pillar, the press must also be free from capitalism and politics. a press that does not merely support 
the interests of the owners of capital and perpetuates political power without considering the interests of the larger society. the possibility of freedom of the press institution that is captured by the interests of capitalism and politics, encourages the spirit of citizen journalism. the term citizen journalism to explain the processing and presentation of news by citizens than professional journalists. The face of democracy itself is seen on two sides. First, democracy as the reality of everyday life, secondly, democracy as it is imaged by the media of information. On the one hand there is an image, on the other side there is reality. Between the two is very likely to occur assimilation, or even the disconnection of relationships. The irony of what is happening now is the disconnect between the image and the reality of democracy itself. The exact term used is the simulacrum of democracy, a condition which seems to be democracy but as an image it has experienced deviation, distortion, and even disconnected from the real reality. This distortion usually occurs through systematic images by mass media. Democracy is no longer a real reality, it is the power of the information owner and the ruler of public opinion. Democratization process in a country not only rely on parliament, but also there is mass media, which is a means of communication both the government and the people, and people with the people. The existence of this mass media, both in the category of print and electronic has a variety of coverage, both in terms of issues or circulation or broadcasting. Access to information through the mass media is in line with the principle of democracy, where there is a complete and open transformation for the democratic country, so there is a uniform distribution of information. However, in practice, many factors hamper this communication process, mainly due to the limitations of mass media in reaching outback locations.

The existence of community radio is one of the answers from the search for solutions to the problems of dissemination of access and means of communication that become the work of the general mass media. In its development, community radio has proven a significant role in the midst of complicated issues of access to information and communication as well as in the role of social control and performs four other functions of the press.

The freedom of the press we are enjoying now brings out previously unexpected things. The voices of the government, for example, have responded in their distinctive language; the press has gone too far While from the social side, there is also a more concurrent reaction is physical.

Perhaps, the press has produced various excesses. And it became more and more apparent. That freedom of the press will bring out a natural consequence. The one that should be anticipated is how to get too far and not be accepted as fairness.

\section{References}

Blair, J., \& Lacy, M. G. (1993). from the SAGE Social Science Collections . Rights Reserved . The ANNALS of the American Academy of Political and Social Science, 503(1), 122136.

Bratic, V. (2008). International Communication Gazette. https://doi.org/10.1177/1748048508096397

Derville, G. (2017). The power of the media (4 th editi). Presses Universitaires de Grenoble, Coll. "Politics and more." 
Gitlin, T. (2009). Media Sociology. Springer, 6(2), 205-253.

Haase, J., Ge, M., Vedel, H., \& Calais, E. (2003). Accuracy and Variability of GPS Tropospheric Delay Measurements of Water Vapor in the Western Mediterranean. Journal of Applied Meteorology, 42(11), 1547-1568. https://doi.org/10.1175/15200450(2003)042<1547:aavogt>2.0.co;2

Helmke, G., \& Levitsky, S. (2004). Helmke, Levidsky (2004) Informal institutions and comparative ploitics; a research agenda. 2(4).

Katz, D., \& Suchey, J. M. (1989). Race Differences in Pubic Symphyseal Aging Patterns in the Male. 172.

McClung, L. A. (1949). LAZARSFELD, PAUL F., BERNARD BERELSON, and HAZEL GAUDET. The People's Choice: How the Voter Makes Up His Mind in a Presidential Campaign. (Second edition.) Pp. xxxiii, 178. New York: Columbia University Press, 1948. \$2.75. The ANNALS of the American Academy of Political and Social Science, 261(1), 194-194. https://doi.org/10.1177/000271624926100137

McCombs, M., \& Shaw, D. (2016). The Agenda-Setting function of mass media. Agenda Setting: Readings on Media, Public Opinion, and Policymaking, 17-26. https://doi.org/10.4324/9781315538389

Robinson, P. (2016). Moving media and conflict studies beyond the CNN effect Eytan Gilboa Maria Gabrielsen Jumbert Jason Miklian. 42(0134), 654-672. https://doi.org/10.1017/S026021051600005X

Shanahan, E. A., Mcbeth, Æ. M. K., Hathaway, Æ. P. L., \& Arnell, R. J. (2008). Conduit or contributor? The role of media in policy change theory. 115-138. https://doi.org/10.1007/s11077-008-9058-y

Tchakhotine, S. (1988). Le viol des foules par la propagande politique (p. 605). p. 605. Retrieved from http://www.amazon.fr/viol-foules-par-propagandepolitique/dp/2070727270

Ukka, I. T. I., \& Kombate, B. (2019). A research on the role played by local and international media into conflict. International Journal of Applied Research in Social Sciences, 1(2), 41-55. 